\title{
Temporal variation of total mercury concentrations and burdens in the liver of eelpout Zoarces viviparus from the Forth Estuary, Scotland: implications for mercury biomonitoring
}

\author{
Scot Mathieson ${ }^{1 *}$, Stephen G. George ${ }^{2}$, Donald S. McLusky ${ }^{1}$ \\ ${ }^{1}$ Department of Biological and Molecular Sciences, University of Stirling, Stirling FK9 4LA, United Kingdom \\ ${ }^{2}$ N.E.R.C. Unit of Aquatic Biochemistry, University of Stirling, Stirling FK9 4LA, United Kingdom
}

\begin{abstract}
The utility of fishes as biomonitors for mercury in aquatic environments is widely recognised, with skeletal muscle as the tissue normally chosen for most monitoring programmes. The liver may also be a suitable candidate tissue for monitoring, as it concentrates many pollutants to higher levels than muscle, and is closely involved with processes of metal dynamics, storage, and detoxification. Little consideration has been given previously to the validation of the use of liver for mercury biomonitoring, with regard to quantifying natural temporal variation. This study considered such variation in the eelpout Zoarces viviparus L., a resident estuarine fish species collected from a subtidal site near a formerly major industrial mercury discharge in the Forth Estuary, eastern Scotland. Liver and skeletal muscle mercury concentrations, liver weight, and body size variables were measured for 196 individual eelpout in seven 3-month periods. Liver Somatic Index (LSI) was significantly higher, and liver mercury concentrations significantly lower, in the summer than in other seasons. Liver mercury burden (the mass of liver mercury per fish), in contrast, showed only limited significant seasonal variation relative to body size, implying that the observed seasonal variation of liver mercury concentration (by around a factor of 3 between summer and winter) results largely from the dilution of similar burdens by a seasonally growing and shrinking liver. Such natural seasonal variation may confound the use of the muscle/liver mercury concentration ratio, which has been proposed as evidence of fish migration between waters with different levels of mercury contamination. These results also suggest that, as variation in liver mercury concentrations is closely related to seasonal variation in LSI, liver tissue may not be a reliable monitor for mercury in temperate species of marine fishes with seasonally fluctuating liver size.
\end{abstract}

KEY WORDS: Mercury · Biomonitoring · Liver - Fishes - Zoarces viviparus · Forth Estuary, Scotland

\section{INTRODUCTION}

The utility of fishes as biomonitors for mercury in aquatic environments is widely recognised (e.g. Phillips 1977, Bryan et al. 1985, Jensen \& Cheng 1987, Evans et al. 1993). The purpose of such biomonitoring is usually the provision of continuing assurance of marine foodstuffs with respect to human health, or monitoring in relation to waste disposal or discharge (Franklin 1991).

\footnotetext{
- Present address: Aquatic Environments Branch, Scottish Natural Heritage, 2 Anderson Place, Edinburgh EH6 5NP, United Kingdom. E-mail: aeb@rasdsnh.demon.co.uk
}

As such, therefore, the tissue of choice for most monitoring programmes has been muscle tissue, this constituting the principal route of exposure of humans to mercury through the diet.

Fish liver has also been used as a target tissue in monitoring programmes for metals in the USA and Denmark (Evans et al. 1993, Jensen \& Cheng 1987). The ratio of mercury concentrations in the muscle and liver tissues of cod Gadus morhua was proposed by Juhlshamn et al. (1982) to provide possible evidence for migration between waters with different levels of mercury contamination. The liver may be a suitable candidate tissue for such monitoring, as it concentrates 
many pollutants to higher levels than muscle (Evans et al. 1993), and is closely involved with processes of metal dynamics, storage, and detoxification (George 1991). Fish liver is already used routinely as a monitoring tissue for lipid-soluble persistent contaminants, such as aromatic organochlorines (e.g. Kammann et al. 1993).

Elliott et al. (1988) summarised the principal hindrance to the use of a fish species as a representative indicator or sentinel organism for the assessment of contaminant levels in a particular habitat as follows: 'Contaminant levels in fish will vary with season, physiological and reproductive condition, sex, size and age, in addition to contaminant exposure. Therefore, the variability due to all but the latter has to be reduced or quantified in order to produce a high signal-to-noise ratio, such that valid spatial and/or temporal trends can be distinguished'. Topping et al. (1975) also recommended that studies of seasonal variation of mercury concentrations should be undertaken for all fish species which are selected for monitoring programmes. This recommendation has been largely disregarded since that time, particularly with respect to the use of liver tissue.

\section{Study area}

The Forth Estuary, a large industrialised estuary on the Scottish east coast (Fig. 1), has been described as one of the most contaminated coastal areas in Scotland with respect to trace metals (Davies 1987). The estuary, uniquely in Scotland, has received inputs of mercury for several decades (Elliott \& Griffiths 1986). The majority of this mercury has been discharged as unrecovered catalyst in a point-source discharge of effluent from an organic chemical manufacturing complex at Grangemouth in the middle estuary (Fig. 1). The annual total load of mercury discharged in the last $20 \mathrm{yr}$ peaked in 1981 with an input of $6 \mathrm{t}$, although inputs from this source had fallen almost to zero by December 1992 [S. Hull, Forth River Purification Board (FRPB), pers. comm.].

\section{Study species}

The eelpout Zoarces viviparus L is a resident estuarine fish species, found commonly in the estuaries around the North Sea and Baltic Sea (Wheeler 1978). This species has a number of characteristics required of any potential indicator species for metals in the aquatic environment (Phillips 1980), including a restricted home range, reasonable longevity loften longer than $4 \mathrm{yr}$, based on annuli on otoliths: S. Math-
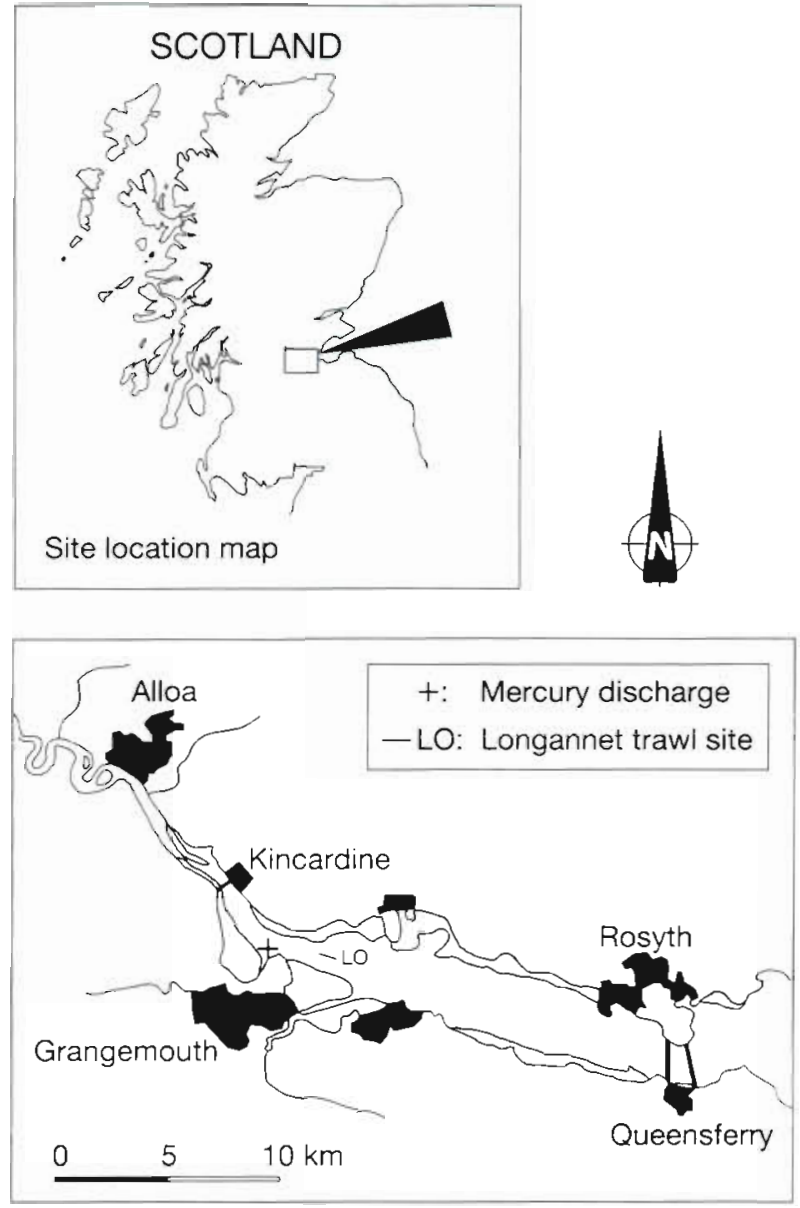

Fig. 1. The Forth Estuary, Scotland, with location of principal mercury discharge and sampling site

ieson pers. obs.), adequate size to provide sufficient tissue for analysis (maximum weight in excess of $100 \mathrm{~g}$ in Forth Estuary: S. Mathieson pers. obs.), abundance and ease of collection. The home range of individual eelpout in the Forth Estuary is unknown, although studies of differences in gene frequency between areas in the Danish belt sea area indicate that the Zoarces population has to be conceived as an array of sub-populations, with very little genetic evidence of mixing as a result of migration between areas only a few tens of kilometres apart (Christiansen et al. 1974, Hjorth \& Simonsen 1975). These same populations were also the subject of an early study by Schmidt (1917), who presented extensive evidence for localised, phenotypically distinct, populations. The eelpout has been proposed by Jacobsson et al. (1986) as a suitable species for use as an indicator of environmental effects of harmful substances, and has been used by Essink $(1980,1988)$ as a bioaccumulation monitoring species for mercury. The eelpout was also reported historically as an important food fish in the Forth Estuary (Day 
1884), and more recently in the Baltic Sea (up to $400 \mathrm{t}$ $\mathrm{yr}^{-1}$ in the Gulf of Riga: Soin 1968), and has, therefore, the potential to be a pathway for mercury to man through diet

As part of a project to assess the utility of the eelpout as a monitoring organism for mercury in estuarine environments (Mathieson 1993), this present study describes the temporal variability of total mercury in liver tissue of this species from a single site in the Forth Estuary, in relation to the seasonal variation of liver size. In addition, total mercury concentrations in skeletal muscle are presented for the same fish, to allow an assessment of the seasonal variation of the muscle/liver mercury concentration ratio. Although much of the mercury stored in fish tissues, and muscle in particular, is in the form of methylmercury (George 1991), total mercury (inorganictorganic forms) is considered here since this is generally the form of mercury for which monitoring is undertaken by the statutory agencies in the UK (S. Hull, FRPB, pers. comm.)

\section{MATERIALS AND METHODS}

Sample collection and mercury analysis. Eelpout were collected from the Forth Estuary subtidal area at Longannet (LO: Fig. 1). Samples were collected by trawling a $1000 \mathrm{~m}$ track, using an Agassiz frame with a $2 \mathrm{~m}$ mouth width and a $15 \mathrm{~mm}$ stretched-mesh net, towed by the FRPB research vessel, 'Forth Ranger'. The LO trawl site was located on each occasion using a DECCA navigation system $\left(56^{\circ} 02.35^{\prime} \mathrm{N}, 03^{\circ} 39.42^{\prime} \mathrm{W}\right.$ to $56^{\circ} 02.35^{\prime} \mathrm{N}, 03^{\circ} 40.41^{\prime} \mathrm{W}$ ). Sampling was carried out approximately monthly between February 1990 and October 1991. Due to inclement weather and mechanical problems with the survey vessel, no samples were collected between December 1990 and February 1991. The ranges of water temperatures for each season (see Table 2) were obtained from FRPB routine water quality monitoring surveys.

Fish were killed on board the research vessel by a sharp blow to the head. Total body length was recorded to the nearest $1 \mathrm{~mm}$. Each fish was then stored individually in a labelled polythene bag in a refrigerator at $4^{\circ} \mathrm{C}$ until the vessel returned to port (maximum $3 \mathrm{~h}$ ). On return to the laboratory, the fresh weight of each fish was then recorded to the nearest $0.01 \mathrm{~g}$. If fish were not dissected immediately, they were re-bagged and placed in a freezer at $-20^{\circ} \mathrm{C}$ until dissection was performed.

The liver was dissected from each fish using stainless steel instruments, weighed (to nearest $0.01 \mathrm{~g}$ ), and refrozen $\left(-20^{\circ} \mathrm{C}\right)$ in individual labelled polypropylene containers until mercury analysis was carried out. An accurately weighed sub-sample of 0.5 to $1.0 \mathrm{~g}$ was taken from larger livers ( $>1.5 \mathrm{~g})$; other livers were analysed whole. An accurately weighed sub-sample of skeletal muscle $(0.1$ to $1.0 \mathrm{~g})$ was also sampled from the long post-anal tail of each fish and treated in the same manner as liver samples. Tissue samples were dried to constant weight in Teflon pressure digestion vessels (Valtech Plastics plc, Thirsk, UK). Tissues were digested in the same vessels (sealed), in $5 \mathrm{ml}$ of concentrated nitric acid, at $110^{\circ} \mathrm{C}$ for $1 \mathrm{~h}$. Cooled solutions were diluted to $10 \mathrm{ml}$ with distilled deionised water (Milli-Q). Mercury was analysed by cold vapour atomic absorption spectrophotometry (CVAAS). A standard reference material (Standard Dogfish Muscle, DORM1, National Standards Bureau of Canada), subjected to the same preparation and analysis as tissue samples, gave a high recovery of mercury (mean $=92.8 \%$, relative standard deviation $=10.8 \%, \mathrm{n}=10$ ).

Data treatment and statistical analysis. To facilitate the assessment of temporal variation, samples were grouped in 3-month 'seasons' as follows: DecemberFebruary (winter), March-May (spring), June-August (summer), September-November (autumn). These are not purely arbitrary divisions, as they reflect the seasonal differences in water temperature in the Forth Estuary (see Table 1), and correspond to relatively distinct periods in the life cycle of the eelpout (e.g. summer: seasonal peaks in liver and testes size; autumn: hatching and rapid growth of viviparous brood in female ovarian cavity; winter: slowed growth of brood and eventual emergence from female).

The Liver Somatic Index (LSI) was calculated for each fish as: $100 \times$ (liver wet weight)/(body fresh weight). For female fish carrying a brood, the weight of the brood was subtracted from the fresh weight prior to calculating the LSI. There were no significant differences between the sexes, when seasonally grouped, in terms of LSI ( $t$-tests, all p >0.05), mercury concentrations ( $t$-tests, all $p>0.05)$ or liver mercury burdens (with respect to length; analysis of covariance, all $p>0.05$ ). Male and female sub-sets were combined, therefore, within seasons. Young-of-the-year fish, recruited into catches in summer only (becoming $1+$ fish the following season), were excluded, as their livers provided insufficient material for analysis. Where there was no significant effect of body size (as length or weight) on LSI or liver Hg concentration, comparisons of mean values between seasons were performed using analysis of variance (ANOVA). Where body size had a significant effect (e.g. on liver $\mathrm{Hg}$ burden, muscle $\mathrm{Hg}$ concentration and, in some seasons, LSI and liver Hg concentration), seasonal samples were compared using an analysis of covariance (ANCOVA). Statistical methods were performed according to the methods in Zar (1984). All differences were taken as significant at the $5 \%$ probability level. 


\section{RESULTS}

\section{Relationships with body size}

Data were collected from a total of 196 eelpout in seven 3-month seasons (Table 1). The effect of body size (as both length and weight) on LSI, liver Hg burden, and liver and muscle $\mathrm{Hg}$ concentrations was investigated within single seasons using Pearson correlation and linear regression. LSI showed no significant correlation with either length or weight in any season in 1990 (Table 1). In 1991, however, LSI varied significantly with body size in spring and autumn, but not in summer. Liver $\mathrm{Hg}$ concentration did not vary significantly with body size in any season, except summer 1991 (Table 1). Liver Hg burdens (the total mass of liver $\mathrm{Hg}$ per fish) increased with size of fish, the $\log _{10}$ of $\mathrm{Hg}$ burden increasing in a highly significant linear relationship with increasing length in 6 of 7 seasons (Table 2). The $\log _{10}$ of muscle Hg concentration showed an increase with length in all seasons, although linear regressions were significant in only 4 seasons (Table 3 ). Coefficients of variation $\left(R^{2}\right)$ indicated that length accounted for a maximum of $72 \%$ of the variation in muscle $\mathrm{Hg}$ concentration in a single season (spring 1991) and, in all other seasons, for less than $40 \%$

\section{Seasonal variability within years}

Seasonal variation was observed in LSI (Fig. 2), with peak mean values in the summers of both 1990 and 1991. Seasonal LSI means were compared within each year, and significant differences were indicated between sea-

Table 1 Zoarces viviparus. Seasonal Pearson correlation statistics (r, p) for liver somatic index (LSI) and liver $\mathrm{Hg}$ concentration versus measures of body size (length and weight) for eelpout from Longannet, Forth Estuary

\begin{tabular}{|c|c|c|c|c|c|}
\hline \multirow[t]{3}{*}{ Period } & \multirow{3}{*}{$\begin{array}{l}\text { Sample } \\
\text { size } \\
\text { (n) }\end{array}$} & \multicolumn{4}{|c|}{ Pearson correlation coefficient } \\
\hline & & \multicolumn{2}{|c|}{ LSI with: } & \multicolumn{2}{|c|}{ Liver $\mathrm{Hg}$ conc. with: } \\
\hline & & length & weight & length & weight \\
\hline Winter 1990 & 31 & $0.23, \mathrm{~ns}$ & $0.10, \mathrm{~ns}$ & $0.012, \mathrm{~ns}$ & $-0.01, \mathrm{~ns}$ \\
\hline Spring 1990 & 45 & $0.02, \mathrm{~ns}$ & $0.05, \mathrm{~ns}$ & 0.04 , ns & $0.10, \mathrm{~ns}$ \\
\hline Summer 1990 & 52 & $0.19, \mathrm{~ns}$ & $0.15, \mathrm{~ns}$ & -0.17 , ns & $-0.23 \mathrm{~ns}$ \\
\hline Autumn 1990 & 6 & $0.36, \mathrm{~ns}$ & $0.46, \mathrm{~ns}$ & $-0.32, \mathrm{~ns}$ & $-0.25, \mathrm{~ns}$ \\
\hline Spring $1991^{\mathrm{a}}$ & 9 & 0.74 & $0.71, \cdot$ & $0.34, \mathrm{~ns}$ & $0.24, \mathrm{~ns}$ \\
\hline Summer $1991^{\mathrm{a}, \mathrm{b}}$ & b 34 & $0.03, \mathrm{~ns}$ & $0.10, \mathrm{~ns}$ & $-0.48, \cdots$ & $-0.44, \cdots$ \\
\hline Autumn $1991^{\mathrm{a}}$ & 19 & $0.65, \cdots$ & 0.53 & $0.18, \mathrm{~ns}$ & $0.16, \mathrm{~ns}$ \\
\hline \multicolumn{6}{|c|}{$\cdot p<0.05, \cdots p<0.01 ;$ ns: not significant $(p>0.05)$} \\
\hline \multicolumn{6}{|c|}{$\begin{array}{l}\text { Regressions }(y=a+b x) \text { of LSI on length-Sp: } a=-0.04107, b=0.00879 \\
\text { Su: } a=2.73939, b=0.00073 ; \text { Au: } a=-0.25872, b=0.00911 \\
\text { Regressions of liver Hg conc, on length-Sp: } a=0.02712, b=0.00038 \\
\text { Su: } a=0.27208, b=-0.0010 ; \mathrm{Au}: a=0.08016, b=0.00032\end{array}$} \\
\hline
\end{tabular}

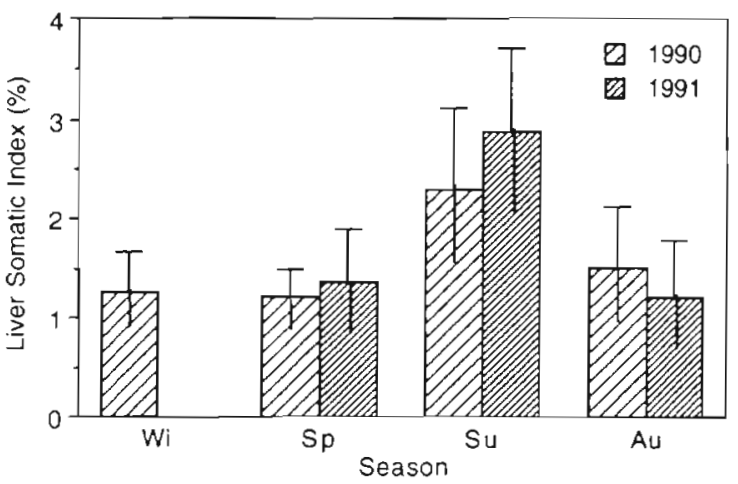

Fig. 2. Zoarces viviparus. Seasonal and annual variation of liver somatıc index for eelpout from Longannet, Forth Estuary

sonal means in 1990 (ANOVA, $F=34.674$, betweengroups $\mathrm{df}=3$, within-groups $\mathrm{df}=130, \mathrm{p}<0.001$.). Multiple comparison testing (Scheffé) indicated that the mean LSI in summer was significantly higher $(p<0.05)$ than those of spring and summer in that year. In 1991, due to a significant correlation between LSI and body size in 2 of the 3 seasons, seasonal differences in the regression of LSI on length were tested using analysis of covariance (ANCOVA) (regression statistics are given in the foot notes in Table 1). The regression elevation (a) for Summer 1991 was significantly higher than those for Spring and Autumn $(F=31.058, \mathrm{df}=2,56, \mathrm{p}<0.0005$; Tukey: Su vs $\mathrm{Sp}, q=6.708, \mathrm{p}<0.001$; Su vs $\mathrm{A} u, q=8.325, \mathrm{p}<0.001$ ).

Liver mercury concentrations also showed seasonal variations (Fig. 3), with a minimum mean value in summer of both years, higher values in spring and autumn, and a maximum mean value in winter of 1990. Differences between seasons were statistically significant in 1990 (ANOVA: $F=13.732$, df $=3,130, p<$ $0.0001)$. A Tukey multiple comparison test indicated that the summer mean was significantly lower than the winter and spring means $(p<0.05)$. Due to a significant effect of body size on liver Hg concentration in summer 1991, differences between the three seasons were investigated using ANCOVA of the regressions of liver $\mathrm{Hg}$ concentration on length (regression statistics are given in the footnotes in Table 1). Although a significant difference was indicated between regression slopes $(F=$ 4.359, df $=2,56, p<0.025$ ). Tukey testing was insufficiently powerful to identify the significant comparisons (all p > 0.50). There was no significant correlation between liver and muscle $\mathrm{Hg}$ concentrations in any of the 7 seasons (Table 3), and correlation coefficients were extremely low in most cases ( 0.1 or lower). 
Table 2. Body size statistics, linear regressions for $\log _{10}$ liver mercury burden $(y)$ on $\log _{10}$ length $(x)$, and estimated liver mercury burdens of eelpout Zoarces viviparus, and water temperatures from Longannet, Forth Estuary. Sample sizes are given in Table 1

\begin{tabular}{|c|c|c|c|c|c|c|c|c|c|c|c|}
\hline \multirow[t]{2}{*}{ Period } & \multicolumn{2}{|c|}{ Length (mm) } & \multicolumn{2}{|c|}{ Welght $(g)$} & \multicolumn{3}{|c|}{ Regression $(y=a+b x)$} & \multicolumn{3}{|c|}{ Hg burden $(\mu g)$} & \multirow{2}{*}{$\begin{array}{l}\text { Water temp. }{ }^{\mathrm{C}} \\
\text { Range }\left({ }^{\circ} \mathrm{C}\right)\end{array}$} \\
\hline & Mean & Range & Mean & Range & a & $b$ & $R^{2}(p)^{a}$ & Estimate $^{b}$ & $95 \%$ & $\mathrm{Cl}$ & \\
\hline Winter 1990 & 174.2 & $105-282$ & 24.2 & $4.2-99.9$ & -8.82 & 3.32 & $0.45(\cdots)$ & 0.025 & 0.019 & 0.033 & $4.9-6.6$ \\
\hline Spring 1990 & 160.7 & $100-209$ & 16.4 & $2.9-35.8$ & -9.49 & 3.52 & $0.41(\cdots)$ & 0.014 & 0.012 & 0.018 & $7.2-13.4$ \\
\hline Summer 1990 & 150.9 & $85-263$ & 27.6 & $3.0-76.5$ & -8.37 & 3.01 & $0.65(\cdots)$ & 0.015 & 0.012 & 0.018 & $13.0-16.8$ \\
\hline Autumn 1990 & 125.4 & $98-195$ & 10.5 & $3.6-30.9$ & -6.41 & 2.02 & 0.20 (ns) & 0.010 & 0.002 & 0.036 & $12.6^{d}$ \\
\hline Spring 1991 & 143.4 & $102-214$ & 14.3 & $2.7-35.0$ & -13.37 & 5.24 & $0.83(\cdots)$ & 0.011 & 0.006 & 0.019 & $8.6-12.2$ \\
\hline Summer 1991 & 164.9 & $91-257$ & 34.0 & $6.6-68.3$ & -10.81 & 4.13 & $0.72(\cdots)$ & 0.015 & 0.012 & 0.019 & $13.4-18.8$ \\
\hline Autumn 1991 & 157.3 & $95-240$ & 18.8 & $2.7-54.6$ & -11.98 & 4.66 & $0.84(\cdots)$ & 0.014 & 0.011 & 0.018 & $5.0-16.0$ \\
\hline \multicolumn{11}{|c|}{$\begin{array}{l}\text { 'Surface water temperature from Forth River Purification Board routine water quality sampling, taken at Grangemouth, on } \\
\text { south bank opposite Longannet (see Fig. 1) }\end{array}$} & ngemouth, on \\
\hline${ }^{d}$ Identical mea & rements & s on 2 sepa & ate date & & & & & & & & \\
\hline
\end{tabular}

Table 3. Zoarces viviparus. Seasonal linear regression statistics for $\log _{10}$ muscle Hg concentration $(y)$ on length $(x)$, mean muscle: liver $\mathrm{Hg}$ concentration ratios, and Pearson correlations (muscle versus liver Hg concentrations) for eelpout described in Table 1

\begin{tabular}{|c|c|c|c|c|c|c|c|c|}
\hline \multirow{2}{*}{ Period } & \multirow{2}{*}{$\begin{array}{l}\text { Sample } \\
\text { size (n) }\end{array}$} & \multicolumn{3}{|c|}{ Linear regression $(y=a+b x)$} & \multicolumn{2}{|c|}{ Muscle:liver Hg Ratio } & \multicolumn{2}{|c|}{ Pearson $r$} \\
\hline & & $a$ & $b$ & $R^{2}(p)^{a}$ & Mean & SD & r & $\mathrm{p}^{a, b}$ \\
\hline Winter 1990 & 31 & -1.2466 & 0.0022 & $0.06(\mathrm{~ns})$ & 1.81 & 1.57 & 0.06 & ns \\
\hline Spring 1990 & 45 & -1.7279 & 0.0049 & $0.26(\cdots)$ & 2.04 & 2.44 & 0.26 & ns \\
\hline Summer 1990 & 52 & -1.6183 & 0.0027 & $0.24(\cdots)$ & 3.64 & 2.93 & -0.03 & ns \\
\hline Autumn 1990 & $5^{c}$ & -1.4637 & 0.0011 & 0.03 (ns) & 1.96 & 1.45 & 0.10 & ns \\
\hline Spring 1991 & 9 & -1.9173 & 0.0050 & $0.72(\cdots)$ & 1.72 & 1.34 & 0.08 & ns \\
\hline Summer 1991 & 34 & -1.0119 & -0.0008 & 0.01 (ns) & 2.78 & 2.18 & 0.01 & ns \\
\hline Autumn 1991 & 19 & -1.4402 & 0.0035 & $0.37(\cdots)$ & 2.24 & 1.79 & 0.07 & ns \\
\hline
\end{tabular}

Total mercury burdens of livers increased in a nonlinear fashion with body size, as length. Logarithmic transformation (base 10) of both variables rendered the associations linear. The linear distribution of $\log _{10}(\mathrm{Hg}$ burden) with $\log _{10}$ (total length) is shown for each season in 1990 (Fig. 4a) and 1991 (Fig. 4b), with regression statistics in Table 2. All relationships were statistically significant, except for autumn 1990, which was based on the smallest sample size, and the most restricted range of lengths of any season. Seasonal variation of the regressions was investigated within each year using ANCOVA. In 1990, there was no significant seasonal variation between the slopes of the 4 regressions $(F=1.616$, df $=3,126, \mathrm{p}>0.10)$. A significant difference among the elevations of these regressions $(F=5.78, \mathrm{df}=3,129, \mathrm{p}<0.0025)$ was identified by Tukey testing between winter and spring regressions $(q=5.03, \mathrm{df}=4,126, \mathrm{p}<0.005)$. No other comparisons between seasons were significant (all $\mathrm{p}>0.05$ ). In
1991, a significant difference between the slopes of the regressions from the 3 seasons $(F=7.61$, df $=2,56$, $p<0.005$ ) could not be identified by Tukey testing (all

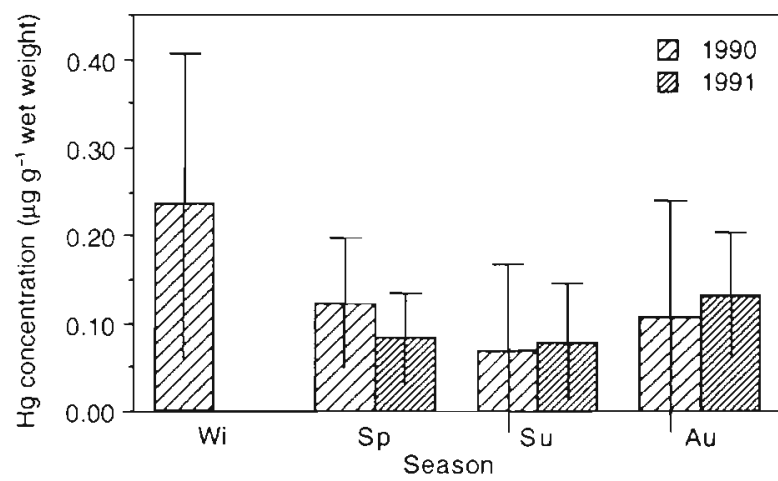

Fig. 3. Zoarces viviparus. Seasonal and annual variation of mercury concentrations in the liver of eelpout from Longannet, Forth Estuary 

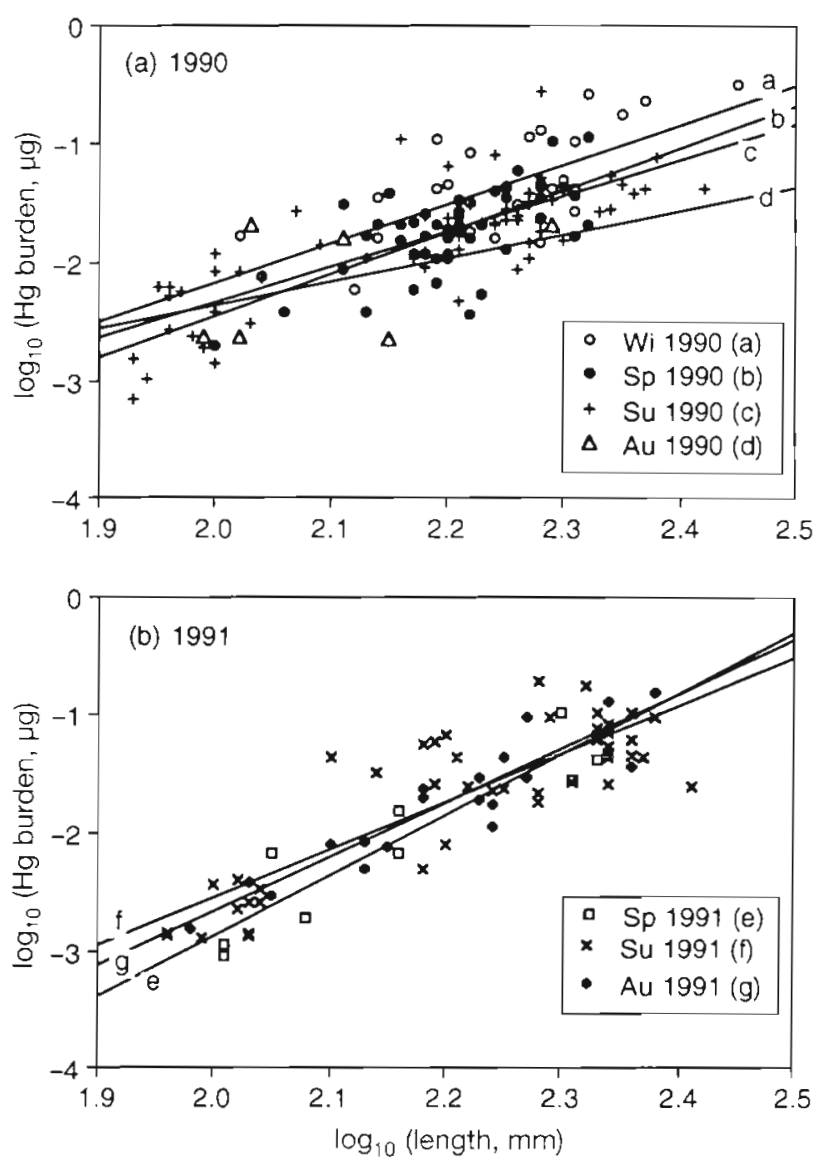

Fig. 4. Zoarces viviparus. Variation of liver mercury burden with fish length for eelpout from Longannet. Forth Estuary

$p>0.05$ ), indicating that a Type II error had been committed. Estimates of liver mercury burden for a $150 \mathrm{~mm}$ fish, calculated from the seasonal regressions, indicate that, allowing for the effects of size, the range of mercury burdens is similar in most seasons.

As the $\log _{10}$ of muscle $\mathrm{Hg}$ concentration increased significantly with length in the majority of seasons (Table 3), seasonal differences were investigated by comparing seasonal regressions using ANCOVA. In 1990, seasonal regressions were similar in terms of the regression slopes $(F=0.896$, df $=3,125, \mathrm{p}>0.50)$, although a significant difference was indicated between regression elevations $(F=15.521$, df $=3,128, p<$ $0.0005)$. Tukey testing was not sufficiently powerful, however, to detect a significant difference between the 2 least similar elevations, from winter and spring $A$ significant difference between the 3 seasonal regressions in 1991 (slopes: $F=4.654$, df $=2.56, \mathrm{p}<0.025$ ) lay between the slopes of the spring and summer regressions (Tukey: $q=3.788, \mathrm{df}=3,56, \mathrm{p}<0.05$ ).

The mean muscle:liver mercury concentration ratio showed a distinct seasonal pattern, with a maximum seasonal value in summer of both years (Table 3 ).
Comparisons between seasons were performed on $\log _{10}$-normalised data, with a significant difference indicated in 1990 (ANOVA: $F=3.2109$, df $=3,129, \mathrm{p}=$ 0.025), between summer and winter means (Scheffé testing, $p<0.05$ ). Differences between the means of the 3 seasons in 1991 were, however, not significant (ANOVA: $F=0.3219, \mathrm{df}=2,59, \mathrm{p}>0.50$ ).

\section{DISCUSSION}

\section{Seasonal variation of mercury in the liver}

No previous studies of seasonality in fish liver mercury concentrations and burdens can be found in the considerable published literature on mercury in fish. This may reflect a reluctance to explore the use of tissues other than muscle for monitoring mercury, or perhaps that other workers have indeed explored its use, found it unsatisfactory for the purpose, and failed to publish such a negative result. Nonetheless, the important roles played by the liver, as outlined above, in the dynamics and storage of metals in fish make it a tissue with a potential for consideration for use in monitoring programmes for mercury.

An essential part of such monitoring is the exploration of the natural dynamics of mercury in the liver tissue, in relation to biological parameters. The significant seasonal differences observed in mercury concentrations in the liver of eelpout are generally not reflected by such strong seasonal variations in the total liver mercury burdens, although some significant seasonal differences in burdens were noted. If the liver undergoes a large increase in size relative to body weight, such as the increase noted between spring and summer, but the total mercury burden of the liver remains fairly similar (see estimates in Table 2 ), then a fall in mercury concentration would inevitably result. This suggests that the seasonal variations observed in mercury concentrations are, at least partially, the result of the dilution and concentration of relatively similar seasonal burdens by the significant seasonal growth and shrinkage of the liver.

\section{Seasonal variation of the LSI}

The seasonal pattern of variation in the LSI observed for eelpout in this study, with significantly higher values of LSI in summer, has been observed in several studies, of eelpout (Korsgaard \& Petersen 1979) and other fish in temperate waters (cod Gadus morhua: Jangaard et al. 1967; plaice Pleuronectes platessa: Dawson \& Grimm 1980, White \& Fletcher 1985, George et al. 1990; winter flounder Pleuronectes americanus: 
Fletcher \& King 1978; burbot Lota lota: Pulliainen \& Korhonen 1990). The seasonal trend in the LSI of eelpout reported in this study follows that of water temperature in the Forth Estuary (Table 2), a relationship also indicated for the LSI of plaice from north-east Scottish coastal waters by George et al. (1990). The seasonal variation of water temperature indicated in that study, from $3-5^{\circ} \mathrm{C}$ in February to March, to $12-15^{\circ} \mathrm{C}$ in the period August to September, is similar to that in the Forth Estuary. White \& Fletcher (1985) suggested that a seasonal increase in plaice LSI in their study was probably due to a combination of an increase in numbers of hepatocytes, and the deposition of lipid and glycogen in the liver during a period of intense feeding after spawning. The LSI declined again as the lipid and glycogen stores were mobilised during the winter period of poor feeding and maximum gonad development. Thus, the seasonal feeding cycle of the plaice has an important effect on the seasonal variation in liver size. In general, relatively inactive benthic fish tend to store lipids in the liver rather than in muscular tissue (Sargent 1976). Seasonal variations in the amounts of lipid present in fish coincide generally with changes in environmental temperature, but can also be related to changes in the availability of food (Sargent 1976, Henderson \& Tocher 1987).

Seasonal changes in liver size have also been related to the reproductive state of Zoarces viviparus. In a study of lipid metabolism in female $Z$. viviparus from Danish waters, Korsgaard \& Petersen (1979) observed a large increase in liver lipid content, corresponding to a seasonal summer increase in relative liver size = LSI), The LSI reached its maximum size before the initiation of vitellogenesis, or production of yolk for developing oocytes in the ovary, and liver weight remained high during vitellogenic growth. A decrease in liver lipid content took place simultaneously with a large decrease in the level of vitellagenin and the level of serum lipid. This decline in lipid content also coincided with the decrease of the LSI over the autumn and winter. A summer peak in lipid content of the liver was also reported for both sexes in eelpout from the Gulf of Finland (Pekkarinen 1980). The maximum value of the LSI was reached in Danish fish in June, and remained fairly constant at approximately $3 \%$ of body weight until August. During the remainder of the year, the mean LSI was between 1 and $2 \%$, similar to the seasonal values recorded for eelpout in this study.

Although the actual uptake mechanisms for both inorganic and organic mercury species remain to be clearly elucidated, it is known that mercury complexes tightly to proteins in the liver (Carty \& Malone 1979, George 1991). The limited seasonal variation of the total liver burden of mercury, relative to body size, indicates that seasonal increase of lipid content does not correspond to an equivalent increase in the actual content of mercury in the liver. This suggests that lipids may not play a large role in the storage of mercury in the liver of eelpout.

\section{Implications for use of muscle/liver mercury ratio}

The significant seasonal variation of liver mercury concentrations shown for eelpout calls into question the validity of the use of the muscle/liver mercury concentration ratio as an indication of recent mercury exposure in marine fish. The ratio was proposed by Juhlshamn et al. (1982) as a potential indicator of recent mercury contamination of cod. These workers established that, on feeding either inorganic or methylated mercury to cod kept under laboratory conditions, an increase in liver mercury concentration preceded a longer-term increase in muscle mercury concentration. They proposed that a muscle/liver ratio of 1 should indicate that mercury levels in the cod were in equilibrium with those in the environment, while ratios of less than 1 suggested that fish had recently been exposed to higher environmental mercury levels. Mean ratios for wild eelpout in this study were always considerably above 1 and, in the summer of 1990, were in excess of 3.6. Although some of the difference in absolute values between the ratios measured in wild eelpout and those reported for wild cod by Juhlshamn et al. (1982) is likely to be due to inter-specific differences in prey, mercury accumulation, and internal dynamics of mercury once taken in, there is also a clear seasonal effect of the summer drop in eelpout liver mercury concentrations (leading to a higher ratio), which means that the difference to the reported ratio for cod is greater in summer than in winter.

The results presented above for eelpout show that the LSI varies considerably between seasons, a natural variation which may be related to seasonal feeding and the reproductive state. Similarly, the mean mercury concentrations in eelpout liver may be more than 3 times higher in winter than in summer, a difference related mainly to the seasonal variation in the LSI, although also, in part, to changes in the liver mercury burden. The LSI of cod has been shown to vary between 2 and $4 \%$ of body weight from winter to summer (Jangaard et al. 1967), a similar range to that seen in eelpout. It is possible, therefore, that mercury concentrations in cod liver might show seasonal variations similar to those observed for eelpout, even in an environment relatively uncontaminated by mercury. This highlights the danger of making assumptions about the ratios of mercury concentrations in different tissues, and ascribing changes to differences in environmental mercury levels, without considering the underlying 
patterns of natural variability described here. On the basis of these results, it appears that the application of the muscle/liver ratio to wild populations of eelpout as a measure of recent exposure to mercury is likely to be extremely problematical and cannot be recommended.

\section{Implications for use of liver tissue for biomonitoring}

It has been shown here that the use of eelpout liver as a biomonitoring tissue for mercury in estuarine biota is subject to some serious limitations, perhaps leading to the recommendation that liver should be avoided as a routine tissue for monitoring mercury accumulation. It is clear that, in comparison with the use of muscle tissue for monitoring mercury accumulation by fish, liver tissue is likely to provide a greater degree of seasonal variation, partly as a result of the marked and significant changes in liver size with season. This cyclical pattern of annual variation, related to seasonal size changes in the liver, is in addition to any variation of mercury concentrations resulting from variable environmental exposure. The seasonal increase of the LSI of eelpout in summer has been shown by others to be related to an increase in lipid content as a result of vitellogenesis in females (Korsgaard \& Petersen 1979) and, possibly, of seasonal increases of feeding activity in both sexes (Pekkarinen 1980)

The seasonal variation of mean concentrations, however, by a factor of around 3 between winter and summer suggests that performing a meaningful comparison of mean concentrations between samples of fish livers may be fraught with difficulties and use of liver should be avoided unless effects of body size and seasonal variability can be accounted for. This study illustrates the necessity of quantifying such natural sources of variation of mercury in different tissues before including them in a programme of monitoring of mercury bioaccumulation.

Acknowledgements. S.M. was supported by a CASE studentship from the Natural Environment Research Council, in association with the Forth River Purification Board (FRPB). We thank the Director and Board of the FRPB for their support. the crew of the 'Forth Ranger' (J. McManus, D. Johnston, and $T$ Thompson) for their patience and professionalism during sampling, and J. Dobson, S. Hull, M. Elliott (now University of Hull) and A. Griffiths of the FRPB Tidal Waters Section for their assistance and advice. We are also grateful to 3 anonymous referees whose comments greatly improved an earlier version of the manuscript.

\section{LITERATURE CITED}

Bryan GW, Langston WJ, Hummerstone LG, Burt GR (1985) A guide to the assessment of heavy metal contamination in estuaries using biological indicators. Mar Biol Ass UK, Occ Publ No. 4
Carty AJ, Malone SF (1979) The chemistry of mercury in b10logical systems In: Nriagu JO (ed) The biogeochemistry of mercury in the environment. Elsevier/North-Holland Biomedical Press, Amsterdam, 433-479

Christiansen FB, Frydenberg O, Gyldenholm AO, Simonsen $\checkmark(1974)$ Genetics of Zoarces populations. VI. Further evidence, based on age group samples, of a heteozygote deficit in the EstIII polymorphism. Hereditas 77:225-236

Davies IM (1987) Trace metals and organochlorines in the Forth Estuary, Scotland. Proc Roy Soc Edinb 938:315-326

Dawson AS, Grimm AS (1980) Quantitative seasonal changes in the protein, lipid and energy content of the carcass, ovaries and liver of adult female plaice, Pleuronectes platessa. J Fish Biol 16:493-504

Day F (1884) The Fishes of Great Britain and Ireland, Vol 1 Williams and Nordgate, London

Elliott M, Griffiths AH (1986) Mercury contamination in components of an estuarine ecosystem. Water Sci Technol 18 $61-170$

Elliott M, Griffiths A., Taylor CJL (1988) The role of fish studies in estuarine pollution assessment. J Fish Biol 33 (Suppl A):51-61

Essink K (1980) Mercury pollution in the Ems Estuary. Helgoländer Wiss Meeresunters 33:11-121

Essink K (1988) Decreasing mercury pollution in the Dutch Wadden Sea and Erns Estuary. Mar Pollut Bull 19:317-319

Evans DW, Dodoo DK, Hanson PJ (1993) Trace element concentrations in fish livers: implications of variations with fish size in pollution monitoring. Mar Pollut Bull 26 $329-334$

Fletcher GL, King MJ (1978) Seasonal dynamics of $\mathrm{Cu}^{2+}, \mathrm{Zn}^{2+}$ $\mathrm{Ca}^{2+}$ and $\mathrm{Mg}^{2+}$ in gonads and liver of winter flounder ( $P_{\text {seudopleuronectes americanus): evidence for summer }}$ storage of $\mathrm{Zn}^{2+}$ for winter gonad development in females. Can J Zool 56:284-290

Franklin A (1991) Monitoring and surveillance of nonradioactive contaminants in the aquatic enviromment and activities regulating the disposal of wastes at sea, 1988-89. Aquat Environ Monit Rep 26. MAFF Direct. Fish. Res. Lowestoft

George SG (1991) Cell transport and transmembrane transport of some metals. In: Merian E (ed) Metals and their compounds in the environment. VCH Verlagsgesellschaft $\mathrm{mbH}$, Weinheim

George SG, Young P, Leaver M, Clarke D (1990) Activities of pollutant metabolizing and detoxification systems in the liver of the plaice, Pleuronectes platessa: sex and seasonal variations in non-1nduced fish. Comp Biochem Physiol 96C:85-192

Henderson RJ, Tocher DR (1987) The lipid composition and biochemistry of freshwater fish. Prog Lipid Res 26 : $281-347$

Hjorth P, Simonsen V (1975) Genetics of Zoarces populations VII. Geographic variation common to the polymorphic loci $\mathrm{HbI}$ and EstIII. Hereditas 81:73-184

Jacobsson A, Neuman E, Thoresson G (1986) The viviparous blenny as an indicator of environmental effects of harmful substances. Ambio 15:236-238

Jangaard PM, Brockerhoff H, Burgher RD, Hoyle RJ (1967) Seasonal changes in general condition and lipid content of cod from inshore waters. J Fish Res Bd Can 24:607-612

Jensen A, Cheng Z (1987) Statistical analysis of trend monitoring data of heavy metals in flounder (Platichthys flesus). Mar Pollut Bull 18:230-238

Juhlshamn K, Ringdal O, Braekkan OR (1982) Mercury concentration in liver and muscle of cod (Gadus morhua) as an evidence of migration between waters with different 
levels of mercury. Bull Environ Contam Toxicol 29: $544-549$

Kammann U, Landgraff O, Steinhart $H$ (1993) Distribution of aromatic organochlorines in livers and reproductive organs of male and female dabs from the German Bight. Mar Pollut Bull 26:629-635

Korsgaard B, Petersen I (1979) Vitellogenin, lipid, and carbohydrate metabolism during vitellogenesis and pregnancy, and after hormonal induction in the blenny Zoarces viviparus L. Comp Biochem Physiol 63B:245-251

Mathieson S (1993) Mercury accumulation by the eelpout (Zoarces viviparus L.) in the Forth Estuary, Scotland. PhD dissertation, University of Stirling

Pekkarinen M (1980) Seasonal variations in lipid content and fatty-acids in the liver, muscle and gonads of the eelpout Zoarces viviparus (Teleostei) in brackish water. Ann Zool Fenn 17:249-254

Phillips DJH (1977) The use of biological indicator organisms to monitor trace metal pollution in marine and estuarine environments - a review. Environ Pollut 13:281-317

Phillips DJH (1980) Quantitative aquatic biological indicators. Applied Science, London

Pulliainen E, Korhonen K (1990) Seasonal changes in condi-

This article was submitted to the editor tion indices in adult mature and non-maturing burbot. Lota lota (L.), in the north- eastern Bothnian Bay, northern Finland. J Fish Biol 36:251-259

Sargent JR (1976) The structure, metabolism and function of lipids in marine organisms. In: Malins DC, Sargent JR (eds) Biochemical and biophysical perspectives in marine biology, Vol 3. Academic Press, London, p 49-212

Schmidt J (1917) Zoarces viviparus $\mathrm{L}$. and local races of the same. CR Trav Lab Carlsberg 13:277-397

Soin SG (1968) Some features of development of the blenny (Zoarces viviparus (L.)) in relation to viviparity. Prob Ichthyol 8:222-229

Topping G, Pirie JM, Graham WC, Shepherd RJ (1975) An examination of the heavy metal levels in muscle, kidney and liver of saithe in relation to year class, area of sampling and season. CM-ICES/E:34

Wheeler A (1978) Key to the fishes of Northern Europe. Warne, London

White A, Fletcher TC (1985) Seasonal changes in serum glucose and condition of plaice, Pleuronectes platessa L. J Fish Biol 26:755-764

Zar JH (1984) Biostatistical analysis. Prentice-Hall International Ltd, Englewood Cliffs, NJ

Manuscript first received: January 2, 1995

Revised version accepted: January 30, 1996 